\title{
Total Iron Binding Capacity
}

National Cancer Institute

\section{Source}

National Cancer Institute. Total Iron Binding Capacity. NCI Thesaurus. Code C74718.

The determination of the saturation of iron binding sites on serum transferrin proteins. 